\title{
TUNTEIDEN KOGNITIIVISUUS JA OPPIMINEN
}

\begin{abstract}
Tunteet eivät ole järjen vastakohta vaan järjellisen ajattelun perusta. Tunteet tarjoavat informaatiota, jota ilman järki ei pysty muodostamaan kokonaisvaltaista käsitystä todellisuudesta. Tunteet vaikuttavat siihen, mitä havaitsemme, minkälaisia päätelmiä teemme ja millaisiin luoviin ajatuksiin saamme herätteitä. Toisaalta järkeä tarvitaan tunteiden tarjoaman informaation pätevyyden arvioimiseen. Tunteilla on tärkeä merkitys oppimisprosessia motivoivina tekijöinä. Niinpä tunteet ja järki ovat oppimisessa molemminpuolisessa vuorovaikutuksessa.
\end{abstract}

\section{TAPIO PUOLIMATKA}

$\mathrm{T}$ Junteiden merkitykseen oppimisessa on suhtauduttu jännitteisesti läpi ajattelun historian. Yhtäältä tunteet on nähty oppimisen esteiksi. Tunteet ja ajattelu on erotettu toisistaan ja tunteisiin, subjektiivisuuteen ja sisäiseen elämään on suhtauduttu epäluuloisesti. "Järki" ja "sydän" on erotettu toisistaan tavalla, joka on antanut järjelle etusijan ja itsenäisen aseman. Oppimiseen on liitetty kyky ottaa objektiivisen puolueeton asenne opittavaan asiaan tavalla joka on riippumaton oppijan subjektiivisesta näkökulmasta. Oppimisprosessi nähdään harjaantumisena asioiden tarkasteluun ilman tunteiden häiritsevää vaikutusta. (Yob 1997, 43). Tämä asenne on voitu ilmaista esimerkiksi sanomalla, että "rakkaus tekee sokeaksi". Rakastava ihminen ei pysty ottamaan asiaan etäisyyttä, koska hänen tunteensa tekevät hänet intohimoisen kiinnostuneeksi asiasta. Tällaisen kiinnostuksen on ajateltu estävän asiallisen tiedon, mikä mahdollistuu vasta puolueettoman ja tunteettoman asenteen pohjalta.

Tällaisen järjen ja tunteen vastakkainasettelun taustalla on ylikorostunut usko järkeen, jonka katsotaan pystyvän ratkaisemaan ihmiselämän keskeiset ongelmat ulkopuolisen ja tunteista vapaan tarkkailijan näkökulmasta. Järki käsitetään "viileäksi, eritteleväksi, mittaavaksi ja laskelmoivaksi kyvyksi, joka pystyy arvioimaan asioita tunteista riippumatta - sitä paremmin, selkeämmin ja tehokkaammin, mitä vähemmän tunteet sen toimintaa häiritsevät" (Sihvola 1994, 201). Tunteet kuten viha, rakkaus, pelko, sääli, toivo, ilo ja suru ymmärretään sokeiksi, arvaamattomiksi ja hallitsemattomiksi voimiksi, jotka vain sumentavat järjen kirkkautta, koska ne liittyvät ihmisluonnon alempaan, eläimelliseen puoleen. (mt. 201-202.)

Läpi länsimaisen filosofian historian on kuitenkin myös puolustettu ajattelutapaa, jossa tunteita ei ymmärretä sokeiksi

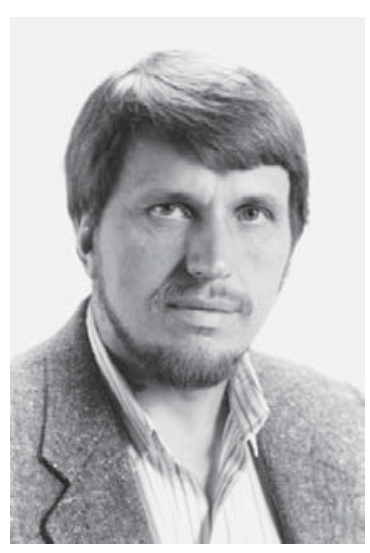

Tapio Puolimatka voimiksi. Monet ajattelijat kuten Platon, Aristoteles, stoalaiset, Descartes ja Spinoza erottivat toisistaan kaksi erilaista inhimillisten tuntemusten tyyppiä. Yhtäällä ovat ruumiilliset tuntemukset, yllykkeet ja halut, joiden synty voidaan selittää puhtaasti fysiologisesti viittaamatta tietoon tai ajatteluun. Toisaalla ovat tunteet kuten rakkaus, viha, suru, sääli, pelko ja toivo, joilla on tietty kohde ja joihin liittyy kohdetta koskevia uskomuksia ja arvostelmia. Ihminen voi olla nälkäinen, ilman että hänen nälällään on selvää kohdetta, mutta kokiessaan pelkoa ihmisellä on mielessään pelon aiheuttaja. Ruumiillisista tuntemuksista poiketen varsinaiset tunteet eli emootiot eivät ole "sokeita", vaan niillä on kohde, jonka ne mieltävät tietynlaiseksi. Olen vihainen ystävälleni, jos uskon hänen pettäneen 
luottamukseni. Olen surullinen, koska arvokas ihmissuhde hajosi väärinymmärrykseen. (mt. 202-204.)

Platonista Spinozaan ulottuvan perinteen johtopäätökset tunteiden arvosta eivät kuitenkaan yhdessä suhteessa eroa ratkaisevasti viime vuosisadan alun tieteisuskoisista käsityksistä, jotka erottivat jyrkästi tunteen ja järjen toisistaan. Molemmissa lähestymistavoissa nähdään tunteet elämän onnistumista häiritsevinä tekijöinä ja tunteiden vaikutusta pidetään haitallisena järjelliselle harkinnalle. Platonista Spinozaan ulottuva perinne ei kuitenkaan näe tunteiden rakennetta sokeana ja hallitsemattomana, koska he katsoivat niiden olevan riippuvaisia uskomuksista. Tunteita voidaan muokata kasvatuksessa vaikuttamalla uskomuksiin. (mt. 205.)

Useat ajattelijat läpi filosofian historian ovat kuitenkin kiinnittäneet huomiota tunteiden myönteiseen merkitykseen oppimisprosessissa. Niinpä esimerkiksi Max Scheler (1915/1963) puolustaa käsitystä, jonka mukaan rakkaus ei tee sokeaksi vaan rakkaus on tiedon edellytys. Soren Kierkegaard (1846/1998) ilmaisee saman asian sanomalla, että totuuden löytämisen edellytyksenä on intohimoinen kiinnostus totuuden löytämiseen. On vaikea oppia mitään ilman riittävää kiinnostusta, koska kiinnostus virittää tiedolliset valmiudet toimimaan tehokkaasti. Kiinnostus palvelee oppimisprosessia, jos se saa inspiraationsa jostakin keskeisestä tiedollisesta arvosta kuten totuudesta. Jos kiinnostusta ohjaa oman edun tavoittelu tai pelkkä pyrkimys mielihyvän kokemiseen, se vie huomion pois totuudesta. Tätä ajattelua on edelleen kehitetty hyveajatteluun perustuvassa perinteessä, jonka mukaan tunteiden harjoittaminen on edellytys oppimisprosessille.

Tämän artikkelin näkökulma perustuu filosofisiin tunneteorioihin. Tarkoituksena ei ole luoda kokonaisvaltaista käsitystä tunteiden ja oppimisen suhteesta vaan tuoda esille joitakin näkökohtia filosofisten tunneteorioiden relevanssista oppimisen tarkastelussa. Tarkoituksena on ensinnäkin etsiä tunteille sellaista määritelmää, joka tekisi oikeutta tunteiden keskeiselle merkitykselle oppimisessa. Oppimisen ymmärrän tässä yhteydessä merkityksessä ‘tietämään tuleminen', ja tiedon ymmärrän klassisen käsityksen mukaan hyvin perustelluksi todeksi uskomukseksi, niin että tietämisessä keskeistä on kosketus todellisuuteen. Tarkastelen ensin filosofisten tunneteorioiden keskeisiä vaihtoehtoja ja argumentoin, että ku- kin niistä tuo esille jonkin tärkeän puolen tunteista. Tämän tarkastelun pohjalta väitän, että tunteissa on useita kognitiivisia aspekteja, joiden välityksellä saamme kokemuksellisen yhteyden todellisuuteen. Tunteiden kognitiivisilla ulottuvuuksilla on keskeinen merkitys oppimisessa. Oppimisen näkökulmasta on tärkeää, että ihminen onnistuu luomaan yhteyden ajattelun ja tunteiden välille voidakseen ajattelussaan käyttää hyväkseen tunteiden tarjoamaa informaatiota. Samalla hänen pitäisi ajattelun kautta pystyä arvioimaan tunteitaan voidakseen eliminoida tunteiden tarjoamaa informaatioita vääristäviä tekijöitä. Niinpä tunteet ja ajattelu ovat monipuolisella tavalla riippuvaisia toisistaan oppimisen näkökulmasta. Tunteet voivat parhaiten palvella oppimista, jos niitä on harjoitettu niin, että ne muodostavat pohjan älyllisen luonteen kehitykselle. Tältä pohjalta korostuu tunteiden merkitys osana älyllisiä hyveitä ja älyllisten hyveiden merkitys oppimisprosessissa.

\section{TUNNETEORIOIDEN VAIHTOEHTOJA}

$\mathrm{N}$ äkemys tunteiden ja oppimisen välisestä suhteesta riippuu omaksutusta tunneteoriasta. Tunteiden tarkastelussa voidaan erottaa ainakin viisi erilaista lähestymistapaa:

(1) Tuntemusteorioiden mukaan tunteet ovat tuntemuksia, jotka voivat olla joko ruumiillisia tai tiettyyn kohteeseen suuntautuvia, intentionaalisia. (2) Behaviorististen teorioiden mukaan tunteet ovat taipumuksia käyttäytyä tietyllä tavalla. (3) Konatiivisten teorioiden mukaan tunteet ovat ilmausta tahdosta ja halusta. (4) Kognitiivisten teorioiden mukaan tunteet sisältävät tietoa ja arviointeja. Tämä teoria voi ilmetä kahdessa erilaisessa muodossa: (4a) kognitiivis-konstruktivistiset teoriat olettavat, että tunteet sisältävät tietoa ja arviointeja, mutta ei varsinaista arvotietoa; (4b) kognitiivis-realistiset väittävät, että tunteet välittävät myös arvotietoa. (5) Yhdistelmäteoriat (komponentiaaliset teoriat) olettavat tunteiden koostuvan usean erilaisen tekijän yhdistelmästä, tavallisimmin tuntemuksesta, halusta ja kognitiosta. (Puolimatka 2004, 19-20; Vrt. Järveläinen 2000.)

Kognitiiviset tunneteoriat ovat erityisen kiinnostavia oppimisen näkökulmasta, koska ne kiinnittävät huomiota niihin moniin tapoihin, joilla tunteet ovat sidoksissa tietoon, arviointiin ja poh- 
dintaan. Kognitiivinen perinne kiinnittää paljon huomiota tunteen ja ajattelun, tunteen ja tiedon väliseen suhteeseen. Kognitiivisen tunneteorian mukaan tunteet sisältävät ajattelua ja ne viestivät informaatiota, koska tunteisiin sisältyy tilannetta koskeva tunnearvostelma. Tällainen arvostelma aiheuttaa ihmisessä tuntemuksia. Tunnearvostelma eroaa pelkästä järjen arvostelmasta siinä, että se on spontaani, vaikuttaa mielentilaan suostuttaen sitä toimimaan tietyllä tavalla ja sen sisältö on aikaisempien tunnetilojen määräämä. (Knuuttila 2000, 73.)

Tunteiden kautta arvioimme tilanteita ja olosuhteita, toimintoja, kohtaloamme, tai tulevan tapahtuman odotettua arvoa. Tunteet kehottavat meitä tekemään jotakin tai varottavat meitä. Huimaus, jota tunnemme kuilun reunalla, kehottaa meitä astumaan taaksepäin. Tähän tunteeseen sisältyvä varoitus pyrkii pelastamaan meidät putoamiselta antamalla meille kuvan putoamisen kauhistuttavuudesta. Toivo antaa uskallusta toimia ja lupaa hyvää ennen kuin omistamme sen. Nämä esimerkit osoittavat, että tunteiden merkitys on eri asia kuin ne tekijät, jotka aiheuttavat tunteen syntymisen.

Tämän käsityksen mukaan tunteita luonnehtii olennaisesti intentionaalisuus, joka tarkoittaa tunteen suuntautumista kohteeseensa. Intentionaalinen ulottuvuus sisältää tietoa, arviointia ja motivaatiota. Tunteen pohjana oleva tieto koostuu ympäristöä koskevasta informaatiosta, arviointi kohdistuu informaation henkilökohtaiseen merkitykseen, motivaatio koskee halujamme ja valmiuttamme toimia kyseisissä olosuhteissa. Jos Ville on kateellinen Tarjalle tämän uudesta autosta, hänen tunteensa perustuu ensinnäkin tietoon Tarjan uudesta autosta, toiseksi se sisältää arvion siitä, että Tarjan auto on hienompi kuin Villen oma auto, ja kolmanneksi se voi sisältää halun ostaa itselleen uusi ja parempi auto.

Kognitiivisten teorioiden edustajat näkevät tavallisesti läheisen yhteyden tunteiden ja niihin liittyvien arviointien sekä arvojen välillä. Teorian sisällä on kuitenkin suuria eroja käsityksissä arvoista ja niiden suhteista tunteisiin. Kognitiivisissa tunneteorioissa voidaan erottaa ainakin kaksi perustavasti erilaista lähestymistapaa arvoihin. Kognitiivis-konstruktivistisen perinteen mukaan arvot palautuvat yhteisön tai yksilön luomuksiksi. Niissä oletetaan, ettei ihmisen tajunnasta riippumatonta arvotodellisuutta ole olemassa eivätkä tunteet siten saata meitä kosketuksiin sen kanssa. Kognitiivis-realistiset teoriat perustuvat näkemykseen, jonka mukaan arvot ovat osa tajunnasta riippumatonta todellisuutta ja tunteiden välityksellä on mahdollista saada tietoa arvoista, eettisistä periaatteista ja elämän tarkoituksesta. Sen mukaan ihmisen on mahdollista päästä kosketuksiin arvojen ja merkityksen perustan kanssa tunteiden välityksellä. Monet keskeiset tunteemme syntyvät kosketuksesta arvotodellisuuteen. Ihmisen minuus ja hänen tärkeimmät tunteensa muotoutuvat arvotietoisuuden pohjalta.

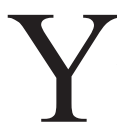

hdistelmäteorioiden mukaan tunnetta ei voi ymmärtää minkään yhden rakenneosan kuten tuntemuksen, käyttäytymistaipumuksen, halun tai arvostelman pohjalta, vaan tunteissa yhdistyy kaksi tai useampia rakenneosia. Klassinen esimerkki yhdistelmäteoriasta on Aristoteleen teoria, jonka mukaan tunteessa on neljä rakenneosaa: arvostelma, tuntemus, psykofyysinen muutos ja toimintasuositus. 1) Tunteeseen kuuluva tunnearvostelma sisältää ajatuksen, että itselle tapahtuu jotakin myönteistä tai kielteistä. 2) Tunnearvostelma synnyttää miellyttävän tai epämiellyttävän tuntemuksen, joka koskee muutosta siinä kuvassa, joka henkilöllä on itsestään. 3) Samalla tapahtuu kyseiselle tunteelle ominaisia fysiologisia muutoksia. 4) Tunteeseen kuuluu vielä sille ominainen toimintasuositus, jonka henkilö voi toteuttaa tai olla toteuttamatta. (Knuuttila 2000, 74-75.)

Tunteet ovat läheisessä kosketuksessa ihmisruumiin biologisiin prosesseihin ja aistihavaintoihin niin, että tunteilla on fysiologinen, biologinen ja psyykkinen perustansa. Tunteisiin vaikuttavat samalla myös monet henkiset ja normatiiviset tekijät kuten ihmisen saama informaatio, looginen ajattelu, sosiaaliset suhteet muihin ihmisiin, esteettiset ja moraaliset elämykset sekä pyhyyden kokemukset. Tunteet avautuvat tai suuntautuvat näiden normatiivisten tekijöiden vaikutuksesta.

Tunteiden tiedollista ulottuvuutta painottava yhdistelmäteoria on modernissa keskustelussa suosituin vaihtoehto. Sen eri muotoja puolustavat William Lyons (1980), Ronald de Sousa (1987), Patricia Greenspan (1988), Justin Oakley (1992), Jon Elster (1999), Aaron Ben Ze'ev (2000) ja Peter Goldie (2000). Modernin keskustelun keskeisiä teemoja on ollut, miten tunteen eri osatekijät kytkeytyvät toisiinsa. Esimerkiksi 
De Sousan mukaan (1987) tunteissa on kognitiivinen osatekijä, tuntemus, käyttäytymiseen liittyvä motivaatio, biologiset juuret ja fysiologisia muutoksia.

Vaikka tunteet erotetaankin ruumiillisista tuntemuksista, ollaan melko yleisesti sitä mieltä, että tunteissa on aspekteja, jotka ovat yhteisiä tunteelle ja sellaisille ruumiillisille olotiloille tai tuntemuksille kuin kivulle, nälälle ja janolle. Tällaisia piirteitä ovat

(1) Fysiologinen aktivoituminen. Useimpiin tunteisiin liittyy fysiologinen aktivoituminen ja erilaisia fysiologisia muutoksia. Ihminen voi esimerkiksi tunteen vaikutuksesta punastua tai tulla kalpeaksi, sydämen lyönti voi kiihtyä tai rauhoittua, ihminen voi alkaa hikoilla tai palella jne. (2) Luonteenomaisia fyysisiä ilmenemismuotoja ja toimintataipumuksia. Fyysisiä ilmenemismuotoja ovat ruumiin asento, äänensävy, hymyileminen, nauraminen, itkeminen ja huutaminen. Tunteen fyysiset ilmenemismuodot ovat läheisessä yhteydessä tunteen aiheuttamaan käyttäytymistaipumukseen. Esimerkiksi häpeä saa ihmisen kätkeytymään tai väistymään tilanteesta. Syyllisyyden tunne saa ihmisen tunnustamaan ja hyvittämään. Pelko saa ihmisen pakenemaan tai puolustautumaan. Kateellinen ihminen saattaa pyrkiä tavalla tai toisella tuhoamaan kateutensa kohteena olevan asian tai sen omistajan.

(3) Lisäksi hyväksytään melko yleisesti se, että tunnetta luonnehtii perustavalla tavalla laadullinen tuntemus (feeling). Tunteiden kaikkein luonteenomaisin piirre on se, miltä ne tuntuvat. Tuntemuksen laatu on erilainen eri tunteissa. Häpeä, syyllisyys, pelko, ilo ja suru tuntuvat erilaisilta.

Yllä olevien piirteiden lisäksi tunteissa on useita kognitiivisia ominaisuuksia, jotka toimivat sille ominaisen tuntemuksen laatua ohjaavina tekijöinä. Tällaisia kognitiivisia tekijöitä ovat spontaani tilannearvio, intentionaalinen kohde, arvoorientaatio.

(4) Spontaani tilannearvio. Jos ihminen esimerkiksi kokee tulevansa nöyryytetyksi ihmisjoukon edessä, hän kokee joko vihaa nöyryyttäjää kohtaan tai häpeää ihmisjoukon edessä tai molempia.

(5) Intentionaalinen kohde. Tunteita erottaa esimerkiksi kivun tai mielihyvän aistimuksista tai tuntemuksista se, että tunteilla on intentionaalinen kohde. Tunnen syyllisyyttä siitä, että rikoin lupaukseni. Olen iloinen siitä, että sää on kaunis. Olen surullinen, koska ystäväni sairastui. Inten- tionaalisen kohteen arvo-ominaisuus määrää paljolti tuntemuksen laatua. Ihaillessani kaunista maisemaa koen sen kauneuden arvon. Omaisuuden tuhoutumisesta johtuva menetyksen tunne perustuu taloudellisiin arvoihin. Syyllisyyden tunne perustuu eettisiin arvoihin, joiden valossa koen omat tekoni tuomittaviksi. Niinpä tuntemuksen laatu vaihtelee sen mukaan, ohjaavatko tuntemuksen syntyä biologiset, loogiset, tekniset, sosiaaliset, taloudelliset, eettiset, esteettiset, oikeudelliset vai uskonnolliset arvot.

(6) Arvo-orientaatio. Tunteille on ominaista tietynlainen arvo-orientaatio, joka perustuu spontaaniin kokemukseen arvojen keskinäisestä tärkeysjärjestyksestä. Arvo-orientaatiossa arvot asetetaan tiettyyn tärkeysjärjestykseen joko tietoisesti tai tiedostamatta. Intentionaalisen kohteen arvo-ominaisuudet saavat näin tietyn aseman ihmisen arvotietoisuudessa, mikä puolestaan omalta osaltaan määrittää tunteen laatua ja intensiteettiä. Oletetaan, että huolimattomuuteni takia kolaroin lomamatkalla olevan perheen kanssa. Tuotan perheelle järkytyksen ja lomamatkan keskeytyksen ja itselleni taloudellisia menetyksiä. Arvoorientaationi määrää, sävyttyykö tunteeni erityisesti eettisen syyllisyyden vai taloudellisten menetysten pohjalta. Jos eettisillä arvoilla on keskeinen asema arvo-orientaatiossani, koen siihen liittyvät tuntemukset erityisen voimakkaina ja hallitsevina.

Yllä olevat kolme kognitiivista ominaisuutta ovat melko yleisesti tunnustettuja. Yleisessä keskustelussa on kuitenkin jäänyt vähemmälle huomiolle tunteille ominainen neljäs kognitiivinen ulottuvuus, jota kutsun tässä nimellä maailmankatsomuksellis-intuitiivinen tunnesävy. (7) Maailmankatsomuksellis-intuitiivista sävyä voidaan luonnehtia intuitiiviseksi kokemukseksi olemassaolon tarkoituksesta ja perimmäisestä luonteesta, mikä sävyttää tai värittää kaikkia tunteita asettamalla ne kokonaisvaltaiseen tunnetaustaan. Tämä intuitiivinen tunnetausta on yhteydessä ihmisen maailmankatsomuksellisiin näkemyksiin. Nämä syvät intuitiot olemassaolon perustavasta luonteesta ja elämän tarkoituksesta värittävät ihmisen tunteita riippumatta siitä, miten hyvin ihminen pystyy tiedostamaan tai suhteuttamaan tätä vaikutusta. Taloudellinen menetys tuntuu erilaiselta buddhalaisesta, joka ajattelee omaisuuden olevan halujen tuottamaa harhaa kuin sellaisesta materialistista, joka ajattelee onnen perustuvan aineelliseen hyvinvointiin. Sairaudet ja vanhene- 
minen tuntuvat erilaisilta sellaisesta ihmisestä, jolla on intuitiivinen vakaumus elämän jatkumisesta kuoleman jälkeen kuin ihmisestä, jonka näkökulma on kokonaan tämänpuoleinen. Moraalinen syyllisyys tuntuu erilaiselta sellaisesta ihmisestä, joka ajattelee moraalin olevan ihmisten keskinäisiä sopimuksia kuin sellaisesta, joka ajattelee niiden olevan Jumalan käskyjä. Vakavat vastoinkäymiset ja kärsimykset tuntuvat erilaiselta ihmisestä, jolla on intuitiivinen kokemus siitä, että koko olemassaoloa ohjaa rakastava, kaikkivaltias ja äärettömän viisas persoona kuin sellaisesta ihmisestä, jonka mukaan olemassaolo on perimmältään persoonaton, tarkoitukseton ja sattumanvarainen. Tällainen perustavien maailmankatsomuksellisten ja uskonnollisten intuitioiden vaikutus ulottuu kaikkiin tunteisiin, koska ne asettavat tunteet tiettyyn taustaan ja siten antavat niille tietyn eksistentiaalis-intuitiivisen sävyn.

Näiden seitsemän tuntomerkin avulla on mahdollista ensinnäkin erottaa tunne halusta, kivun tai mielihyvän aistimuksesta tai ajattelusta. Toiseksi ne voivat auttaa erottamaan, mistä tietystä tunteesta on kysymys. Esimerkiksi syyllisyys ja pelko voidaan erottaa toisistaan niille ominaisen tuntemuksen laadun, intentionaalisen kohteen ja toimintataipumuksen pohjalta.

Tällainen kognitiivis-realistisesti painottuva yhdistelmäteoria tuo esille tunteiden keskeisen merkityksen oppimisessa. Tunteiden välityksellä olemme kosketuksissa arvoihin ja suhteudumme intuitiivisesti todellisuutta koskeviin perimmäisiin kysymyksiin. Tunteen maailmankatsomuksellis-intuitiivinen sävy saattaa oppimisen maailmankatsomukselliseen viitekehykseen, joka värittää kaikkien tosiasioiden tulkintaa.

\section{OPPIMINEN TIEDOLLISENA AKTIVOITUMISENA}

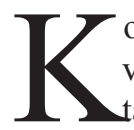

ognitiivis-realistisen yhdistelmäteorian valossa oppiminen ei ole jotakin tunteista irrallista vaan olennaisesti tunteista riippuvaista. Tunteissa itsessään on vahva kognitiivinen elementti, joka tarjoaa ihmiselle todellisuutta koskevaa informaatiota. Voidakseen suhtautua tunteiden tarjoamaan informaatioon kriittisesti, ihmisen on tärkeä kehittää kykyään tulkita ja arvioida tunteitaan. Sen lisäksi että tunteet itse tarjoavat tietoa, ne toimivat myös yleisemmin tiedollisten prosessien motivoivina voimina. Koska asioiden tietäminen edellyttää niiden ym- märtämistä ja niiden tiedollisesta oikeutuksesta varmistumista, oppijan on aktiivisesti käytettävä tiedollisia valmiuksiaan ja itsenäistä arviointikykyään. Tiedollisiin valmiuksiin kuuluvat järjellinen harkinta, havainto, tunteet, intuitio, käytännöllinen toiminta ja muisti. Keskeinen osa tiedollisten valmiuksien aktivoitumista on järkiperäisten tunteiden kehittyminen, koska niiden seurauksena herää kiinnostus opittavaan asiaan ja halu päästä selville totuudesta. Arviointikyvyn kehittäminen ei merkitse pelkästään järjellisen päättelyn kehittämistä vaan olennaista siinä on tunteiden ja intuitioiden syventäminen ja pyrkimys syvempään tiedostamiseen.

Tietäminen edellyttää omakohtaista kosketusta tiedollisiin perusteisiin, tiedollisten valmiuksien aktivoitumista ja omakohtaisen näkemyksen muodostamista. Voidakseen ymmärtää käsitysten tiedollisia perusteita, oppijan tulee suhteuttaa opittuja asioita kokemukseensa, tunteisiinsa ja intuitioihinsa, oppia ymmärtämään asioiden välisiä yhteyksiä ja pystyä liittämään yksityiskohdat laajempaan kokonaisuuteen. Aidon oppimisen seurauksena oppija pystyy lopulta oikeuttamaan uskomuksensa tavalla, joka tekee noista uskomuksista tietoa.

Ajattelu ei ole tunteetonta, vaan tunteet ovat läheisessä suhteessa ajatteluun. Oppiminen ei tapahdu parhaiten tilanteessa, jossa ihminen ei tunne mitään. Kriittinen ajattelija ei ole viileä ja etäinen, sillä tunteet ja järki kuuluvat yhteen. Tunteiden kehitys on älyllisen kehityksen edellytys. Oikealla tavalla suuntautunut ja virittynyt tunne on edellytys menestykselliselle älylliselle työskentelylle.

\section{JÄRKI JA TUNTEET}

I srael Scheffler kiinnittää huomiota oppimisen edellytyksenä oleviin asenteisiin ja onnistuneen oppimiskokemuksen seurauksena herääviin tunteisiin. Scheffler (1991) jakaa tiedolliseen prosessiin vaikuttavat tunteet kahteen ryhmään. Ensimmäinen sisältää yleensä tunteet, jotka palvelevat kriittistä pohdintaa ja tutkimusta, ja toinen sisältää erityisesti kognitiiviset tunteet. Keskityn aluksi jälkimmäiseen ryhmään eli kognitiivisiin tunteisiin.

Kognitiiviset tunteet "liittyvät subjektin kognitioiden (uskomusten, ennustusten, odotusten) sisältöön ja kantavat niiden tietoteoreettista statusta”. (Scheffler 1991, 9.) Kognitiiviset tunteet 
palkitsevat rehellisen oppimisprosessin tuloksena syntyvät oivallukset. Olemme onnellisia koska olemme saaneet tehtävän suoritetuksi tai olemme oppineet jotakin kiinnostavaa. Kognitiivisten tunteiden kohdalla tämä väite koskee erityisesti subjektin kognitioiden luonnetta. Scheffler kiinnittää huomiota erityisesti kahteen kognitiiviseen tunteeseen: ilo siitä, että saamme osoitetuksi jonkin asian todeksi ja yllätyksen kokeminen. (Scheffler 1991; Yob 1997.)

Kognitiiviset tunteet eivät ole niinkään sitoutumista järjen periaatteisiin kuin tunteenomaista vastausta tuloksiin, joita on saatu noudattamalla järjen periaatteita. Kun oppija pyrkii pääsemään asioista selville totuuden kunnioittamisen pohjalta, hän voi kokea ilon tunteita ymmärtäessään selvittäneensä jonkin tiedollisen ongelman. Jos tutkimuksen pohjalta saavutettu käsitys vastasi hänen odotuksiaan ja aavistuksiaan, hän kokee iloa siitä, että onnistui todentamaan oletuksensa. Toisaalta oppimisprosessi voi johtaa hänet täysin odottamattomiin tuloksiin, jotka herättävät hänessä yllätyksen tunteita. Sekä ilo että yllätyksen tunne ovat seurausta siitä, että tutkimusprosessi on toteuteuttu tiukasti pitäytyen kriittisen tutkimuksen periaatteisiin. Jos oppija olisi lähestynyt opittavaa asiaa radikaalin epäilijän tai tietoteoreettisen apatian asenteella, hänellä ei olisi ollut intohimoista kiinnostusta asian selvittämiseen tiettyjen aavistusten pohjalta. Jos taas hänen asenteensa olisi ollut dogmaattinen ja hän olisi kieltänyt kaiken sellaisen informaation, joka uhkaa hänen mieliuskomuksiaan, hän ei olisi voinut kokea tutkimuksen seurauksena tulevia ilon tai yllätyksen tunteita. (Scheffler 1991, 17; Yob 1997, 47.)

Ensimmäisen ryhmän tunteet, jotka palvelevat yleensä oppimista, kriittistä pohdintaa ja tutkimusta, jakautuvat (a) havainnointia ohjaaviin tunteisiin, (b) teoreettiseen mielikuvitukseen ja (c) järkiperäisiin tunteisiin (rational passions).

Havainnointia ohjaavat tunteet vaikuttavat siihen, mitä näemme ja kuulemme, minkälaisena näemme ympärillämme olevan todellisuuden. Tunteilla on tärkeä merkitys siinä, miten näemme ulkopuolisen maailman. Ne auttavat rakentamaan näkemyksen maailmasta ja määrittelemään maailman olennaiset piirteet. Tunteet auttavat meitä orientoitumaan ympäristöömme.

Tunteet tarjoavat herätteitä myös teoreettiselle mielikuvitukselle, joka on tiedollisten keksintöjen ja löytöjen perustana. Ilman mielikuvitusta ei tehdä uusia teoreettisia löytöjä. Teoreettinen kekseliäisyys vaatii rohkeutta. Tunne-elämä tarjoaa monia uusia ideoita, joiden valossa tosiasiat voidaan hahmottaa uudessa valossa. Tunteet auttavat myös valitsemaan erilaisten mallien välillä ja kohdistavat huomion tosiasioiden olennaisiin piirteisiin. Tosiasioilla ja mielikuvituksen luomilla malleilla on kullakin oma tunnearvonsa. Nämä tunnearvot ohjaavat valintaa ja painottamista. $\mathrm{Ne}$ auttavat tekemään teoreettisia ratkaisuja.

Järkiperäisillä tunteilla tarkoitetaan sellaisia tunteita, jotka ovat älyllisten hyveiden ja järkiperäisen luonteen perustana. Tällaiset tunteet ovat pohjana tottumuksille ja toimintataipumuksille, jotka edistävät perustelujen huomioon ottamista, totuuden löytymistä ja yleensä oppimista. Scheffler olettaa, että tunne vaikuttaa ajattelun yhteydessä alusta asti ja että tunne ja järki kehittyvät keskinäisen vuorovaikutuksen ansiosta.

Järjen oikea käyttö edellyttää sitä, että tiedolliset prosessit ohjautuvat järjellisyyden ihanteiden ja periaatteiden mukaisesti. Oikein käytettynä järki ohjautuu ihanteiden ja periaatteiden kuten ristiriidattomuuden periaatteen ja riittävän perusteen periaatteen mukaisesti. Kun tällaiset ajattelun, toiminnan ja arvioinnin mallit sisäistyvät luonteenpiirteiksi, voidaan puhua järkiperäisestä luonteesta. Olennainen osa tällaista luonnetta ovat asiaankuuluvat tunnetaipumukset. Oikeanlaiset tunteet auttavat järkiperäisten periaatteiden sisäistämisessä. Tällainen asenne "vaatii vääristelyn ja kiertelyn inhoamista, teoreettisten saavutusten ihailua, perusteltujen argumenttien kunnioitusta" (Scheffler 1991, 4).

Järjen periaatteiden pohjalta ohjautuva luonne valvoo ja hillitsee välttelyä ja vääristelyä, sotii epäjohdonmukaisuutta, tosiasioiden epäreilua käsittelyä ja toiveajattelua vastaan. Estäessään epätoivottavia taipumuksia pääsemästä hallitsevaan asemaan se tukee tasapainoista ajattelua ja saa ihmisen tekemään oikeutta tiedollisille näkökohdille. Haitallisia tunnetaipumuksia ei kuitenkaan ole mahdollista hallita tunteettoman järjen avulla, vaan hallinta toteutuu kehittämällä tunteita sopivalla tavalla.

\section{ÄLYLLISET HYVEET}

$\mathrm{T}$

Vunteilla on siis tärkeä merkitys oppimisprosessissa, koska ne tarjoavat kosketuksen todellisuuteen ja koska tunteenomaisella kiinnostuksella on tärkeä merkitys oppimista 
motivoivana tekijänä. Tunteet voivat kuitenkin myös ohjata oppimisprosessia harhaan tai häiritä sitä, jos niitä ei ole oikealla tavalla harjoitettu niin, että ne muodostavat perustan järkiperäiselle luonteelle. Järkiperäinen luonne on tottunut noudattamaan oikeita toimintatapoja ja tekemään perusteltuja arvostelmia. Sen perustana olevia toiminta- ja tunnetaipumuksia on antiikin ajoista saakka kuvattu älyllisen hyveen käsitteen avulla. Hyveellä tarkoitetaan harjoituksen ja tottumuksen kautta hankittuja persoonallisuuden ominaisuuksia, jotka ovat pysyviä ja syviä.

Tunteet kuuluvat hyveeseen motivaation osana. Motiivi taas on tunne, joka saa ihmisen toimimaan, jotta hän saavuttaisi tavoitteensa. Motivaatio luonnehtii yksilöä syvällisesti ilmaistessaan hänen tapansa suuntautua ja käyttäytyä (Zagzebski 1996, 136). Älyllisen hyveen käsite tarkoittaa sellaista mielenlaatua, asennetta ja luonteenpiirteitä, jotka edistävät älyllisten taitojen ja tottumusten oikeaa käyttöä. Älyllisten taitojen ja tottumusten oikea käyttö on puolestaan edellytys oppimiselle, sille, että tulemme tietämään asiat olennaisesti sellaisina kuin ne ovat. Älyllisten hyveiden perustana on tunne-elämän tasapaino, itseluottamus ja myönteinen minäkuva, jotka edistävät johdonmukaista ajattelua ja kykyä asettaa asioita oikeisiin yhteyksiin (Siegel 1988, 41).

Älyllisiä hyveitä voidaan luokitella sen mukaan liittyvätkö ne tiedon hankkimiseen, puolustamiseen, viestimiseen tai soveltamiseen. On tietysti olemassa paljon hyveitä, jotka liittyvät näihin kaikkiin vaiheisiin, mutta useiden hyveiden merkitys painottuu erityisesti johonkin näistä vaiheista älyllisissä prosesseissa. (Puolimatka 2004, 128-137.)

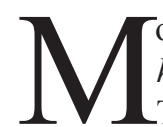
onet keskeiset hyveet liittyvät tiedon hankkimiseen ja totuuden löytämiseen. Totuuden löytäminen edellyttää ensinnäkin hyveitä, jotka motivoivat ihmistä opiskelemaan, saavat hänet paneutumaan tiedon hankkimiseen johdonmukaisesti, intensiivisesti ja pitkäjänteisesti. Tätä varten ihminen tarvitsee tiedonhalua, totuuden rakkautta, älyllistä rehellisyyttä ja lahjomattomuutta. Jos ihminen ajattelee jo tietävänsä kaiken tai on välinpitämätön, hän ei ole halukas oppimaan eikä siten voi omaksua uutta tietoa. Tiedonhaluinen ihminen ei suhtaudu asioihin välinpitämättömästi, viileästi ja etäisesti. Hän on niin kiinnostunut totuudesta, että hän on motivoitunut näkemään ajattelutyöhön tarvittavan vaivan. Hän keskittyy käsiteltävään asiaan perusteellisesti ja järjestelmällisesti ja pohtii siihen liittyviä kysymyksiä huolellisesti. Jos oppijan mieli harhailee muissa asioissa ja siirtyy lyhytjänteisesti asiasta toiseen, hän helposti omaksuu informaatiota pohtimatta sen luotettavuutta. (Wood 1998, 34-35.)

Pelkkä tiedonhalu, pitkäjänteisyys ja valmius nähdä vaivaa ei kuitenkaan takaa sitä, että yksilö omaksuu totuudenmukaisia käsityksiä. Sen lisäksi hän tarvitsee älyllisiä hyveitä, jotka liittyvät tarjolla olevan informaation arvioimiseen, analysoimiseen ja järjestämiseen. Hän tarvitsee kykyä tehdä tarkkoja huomioita, muistaa asiaankuuluvia näkökohtia, pohtia asioiden välisiä yhteyksiä, arvioida osin ehkä ristiriitaistakin todistusaineistoa, analysoida käsityksiä niiden perustekijöihin, erottaa loogisia yhteyksiä ja syy - seuraussuhteita, havaita malleja ja säännönmukaisuuksia, koota irrallisia tosiasioita järjestyneeksi kokonaisuudeksi, ajatella luovasti, omaperäisesti ja itsenäisesti. (Wood 1998, 36. Käsitysten arvioimisessa ihmistä auttavat lisäksi kriittinen avoimuus, älyllinen huolellisuus, systemaattisuus, kyky tunnistaa luotettavia auktoriteetteja, rohkeus sekä hyveet, jotka ovat vastakkaisia toiveajattelulle ja mukautumiselle. Asioiden analysoimisessa ja jäsentämisessä ihmistä auttavat kyky keksiä selityksiä monimutkaisille tosiasioille, nöyryys, joustavuus, ymmärrys ja eheys. (Zagzebski 1996, 166-167.)

Tiedon hankkimiseen ja totuuden löytämiseen liittyvät hyveet eroavat joiltakin osin tiedon puolustamiseen liittyvistä hyveistä. Tiedon puolustamiseen liittyvät hyveet kuten älyllinen rohkeus auttavat ihmistä pitämään kiinni perustelluista käsityksistä silloinkin, kun ne ovat vastakkaisia yleiselle mielipiteelle ja saattavat yksilön alttiiksi kritiikille tai syrjinnälle. Voidakseen puolustaa löytämiään totuuksia yksilön täytyy kehittää ja hioa omaksumiaan käsityksiä. Tätä varten hän tarvitsee monia edellisessä kohdassa mainittuja hyveitä kuten analysointikykyä ja luovuutta. Niiden lisäksi hän tarvitsee dialektisia hyveitä kuten kykyä tehdä oikeutta vastakkaisille argumenteille, tunnistaa niiden perustana olevia olettamuksia ja niiden loogisia seuraamuksia. Hänen täytyy pystyä vastaamaan esitettyyn kritiikkiin luovasti, selkeästi ja perustellusti. Hänen täytyy olla moraalisesti rehellinen niin ettei hän pyri pitämään käsityksistään kiinni silloin, kun ne osoittautuvat kriittisessä tarkastelussa virheelli- 
siksi. Hän ei saa pyrkiä manipuloimaan vastustajiaan ja turvautumaan älyllisesti kyseenalaisiin argumentteihin.

Totuuden puolustamisen tasapuolisuus riippuu ajattelua ohjaavista tunteista. Kateus, ylpeys ja ennakkoluuloisuus estävät ihmistä ajattelemasta puolueettomasti. Älyllinen ylpeys, pelokkuus, mukautuvuus, ennakkoluuloisuus, toiveajattelu ja piittaamattomuus yksityiskohdista haittaavat oikeaa ajattelua. Ihmisellä, jolta puuttuu itsekunnioitusta ja jolla on liian voimakas hyväksytyksi tulemisen halu, on taipumus olla älyllisesti mukautuva. Itsenäisyyttä on tasapainotettava oikealla luottamuksella muihin. Itsekeskeinen ihminen haluaa aina olla oikeassa eikä siksi kiinnitä riittävästi huomiota siihen, mitä muilla on sanottavana. Hän ei ota huomioon tosiasioita, jotka osoittaisivat hänen olevan väärässä. Hän ottaa huomioon vain sellaista informaatiota, joka tukee hänen käsityksiään. (Zagzebski 1996, 159.) Liian epävarma ihminen ei uskalla kuunnella muiden kritiikkiä, koska se horjuttaa liikaa hänen omaa vakaumustaan. Hän joko lukkiutuu omaan käsitykseensä, tai hän mukautuu vallitsevaan käsitykseen tullakseen muiden hyväksymäksi.

Kolmas älyllisten hyveiden luokka koostuu hyveistä, jotka liittyvät tiedon käytännön soveltamiseen. Näihin kuuluvat hallinnan, organisoimisen, kaukokatseisuuden, ongelmanratkaisun ja strategisen ajattelun hyveet. Älyllisesti hyveellinen ihminen suhteuttaa oppimansa asiat omiin tietorakenteisiinsa. Koska hän on sisällöllisesti kiinnostunut opittavan asian ymmärtämisestä, hän jäsentää uudet tiedot osaksi mielekkäitä tietorakenteita niin, että se johtaa myös muutoksiin hänen tavassaan suuntautua käytännöllisten ongelmien ratkaisuun. Hän pyrkii ymmärtämään asioita niin, että hän pystyy soveltamaan tietoaan. Hän osaa soveltaa tietoaan muuallakin kuin vain senkaltaisessa tilanteessa, jossa hän sen oppikin. Uusi tieto vaikuttaa hänen tapaansa katsoa todellisuutta.

Vaikka eri älylliset hyveet painottuvat tiedollisen prosessin eri vaiheissa, hyveellinen persoona muodostaa kokonaisuuden. Yleensä ei pidetä hyveellisenä ihmistä, joka toimii kaukokatseisesti ja analyyttisesti suunnitellessaan rikosta. Se mitä pidetään älyllisesti hyveellisenä tai paheellisena riippuu siitä, miten ominaisuudet niveltyvät hyvän elämän kokonaisuuteen. Niinpä hyveen käsite saa sisältönsä siitä, mitä pidetään hyvänä elämänä. Käsitys hyvästä elämästä voi puolestaan vaihdella eri maailmankatsomuksissa. Tästä syystä älylliset hyveet saavat jossakin määrin erilaisen sisällön sen mukaan ymmärrämmekö hyvän elämän esimerkiksi stoalaisen, aristotelisen, nietzscheläisen, kristillisen tai buddhalaisen maailmankatsomuksen pohjalta. Tätä selventää seuraavanlainen esimerkki. Kristillisen käsityksen mukaan Jumala on äärettömän älykäs persoona, jonka kuvaksi ihminen on luotu. Niinpä kristillisessä kulttuurissa arvostetaan esimerkiksi käsitteiden analysointia ja käsitteiden välisten loogisten suhteiden tunnistamista. Zen buddhalaiset sen sijaan pitävät analyyttista ajattelua älyllisesti paheellisena ja oireena hengellisestä sokeudesta, joka pitää ihmisen sidoksissa uudelleen syntymisen kiertokulkuun. Zenkei Shibayama (1991, 361) on ilmaissut tämän asenteen näin: "Saavuttaakseen vertaansa vailla olevan valaistuksen on luovuttava erottelevasta mielestä. Ne jotka eivät ole ylittäneet estettä ja luopuneet erottelevasta mielestä ovat kaikki aaveita, jotka oleskelevat puissa ja kasveissa." Stoalaiset, aristotelikot, nietzscheläiset, buddhalaiset ja kristityt pitävät kaikki viisautta älyllisenä hyveenä, mutta he ymmärtävät viisauden osin eri tavoin. (Wood 1998, 4647.)

Älylliset hyveet voidaan siis ymmärtää pysyviksi ja luotettaviksi ominaisuuksiksi, jotka ohjaavat älyllistä elämäämme, tapaamme muodostaa käsityksiä, tehdä havaintoja ja päätelmiä hyvän elämän edellyttämällä tavalla. Mikä on tunteen asema älyllisissä hyveissä? Ensinnäkin tunteilla on älyllistä aktiivisuutta motivoiva merkitys. Charles S. Peirce huomautti, että ratkaisemattomat epäilykset jättävät tutkijan "epämukavaan" ja "ärtyneeseen" mielentilaan, joka saa hänet pyrkimään epämukavasta tunteesta vapautumiseen siten, että hän "kiinnittää mielensä johonkin uskomukseen". Miksi ratkaisemattomat epäilykset saattavat tutkijan epämukavaan ja ärtyneeseen tilaan? Syynä lienee se, että tutkija on kiinnostunut totuuden löytämisestä. Hän haluaa päästä selville, miten asiat ovat todellisuudessa. Tällaisellä ihmisellä on totuudellisuuden tai älyllisen rehellisyyden hyve. Ihmisellä, joilla on tällainen "intohimo totuuden löytämiseen", on sen seurauksena suuri joukko tunteita. Hän tuntee iloa uusista löydöistä ja hän tuntee ahdistusta, kun hän ei pysty ratkaisemaan kantaansa johonkin tärkeään kysymykseen. (Wood 1998, 48.)

Tunteet eivät pelkästään motivoi älyllisesti hyveellistä toimintaa vaan myös liittyvät hyveel- 
liseen toimintaan ja ovat sen seurausta. Älyllisesti hyveellinen ihminen saa tyydytystä siitä, että hän pystyy ratkaisemaan vaikean ongelman. Luovat ihmiset tuntevat iloa pystyessään luomaan jotakin uutta tai viemään pitkäaikaisen tutkimusprojektin päätökseen. Se mikä on ihmiselle tärkeää vaikuttaa siihen, miten hän toimii ja mitä hän kokee ja lopulta määrää paljolti sen millainen ihminen hänestä tulee.

Keskeistä älyllisten hyveiden kehittymisessä on tietynlaisen halun kehittyminen: yksilö oppii haluamaan totuuden löytämistä sen sijaan että hän haluaisi joitakin toisarvoisia asioita. Kun totuuden löytämisen halu kasvaa niin voimakkaaksi että se voittaa sen kanssa ristiriitaiset halut, yksilön älyllinen kiinnostus on riittävän voimakasta, niin että se motivoi häntä pitkäaikaiseen älylliseen työskentelyyn. Useimmissa tapauksissa älyllisen hyveen oppiminen edellyttää tunteiden harjoittamista ja totuttelua. Sitä edistää myös sopivien esikuvien saaminen. (Zagzebski 1996, 151, 159-160.)

\section{KOOSTE}

Pohdin tässä artikkelissatunteiden merkitystä oppimisprosessille. Ensinnäkin totesin, että itse tunteessa on kognitiivisia elementtejä, jotka tarjoavat ihmiselle olennaista informaatiota todellisuudesta. Toiseksi tunteet ovat oppimisprosessia motivoivia tekijöitä, joita ilman ihmisellä ei olisi riittävää kiinnostusta perehtyä tutkittavaan asiaan sen vaatimalla perusteellisuudella. Kolmanneksi tunteet vaikuttavat havaintoon, teoreettiseen mielikuvitukseen ja järjelliseen päättelyyn. Kun tunteita oikealla tavalla harjoitetaan, ne muodostavat perustan älyllisten hyveiden kehitykselle, jotka mahdollistavat asioiden perusteellisen pohdinnan ja joilla on keskeinen merkitys oppimisprosessissa.

\section{LÄHTEET}

Ben Ze'ev, Aaron (2000) The Subtlety of Emotions. Cambridge, Mass.: The MIT Press.

De Sousa, Ronald (1987) The Rationality of Emotion. Cambridge, Mass.: The MIT Press.

Elster, Jon (1999) Alchemies of the Mind. Rationality and the Emotions. Cambridge University Press.

Goldie, Peter (2000) The Emotions. Oxford: Clarendon Press.
Greenspan, Patricia (1988) Emotions \&

Reasons. An Inquiry into Emotional Justication. London: Routledge.

Järveläinen, Petri (2000). A Study of Religious

Emotions. Schriften der Luther-Agricola Gesellschaft 47. Helsinki: Luther-Agricola Gesellschaft.

Kierkegaard, Soren (1846/1998). Päättävä epätieteellinen jälkikirjoitus. Suom. Torsti Lehtinen. Porvoo: WSOY.

Knuuttila, Simo (2000). "Tunteet”. Teoksessa

Timo Airaksinen (toim.) Minä vuonna 2000. Otava.

Lyons, William (1980). Emotion. Cambridge University Press.

Oakley, Justin (1992). Morality and Emotions. London: Routledge.

Puolimatka, Tapio (2004). Kasvatus arvot ja tunteet. Tammi.

Scheffler, Israel (1991). In Praise of the Cognitive Emotions. New York: Routledge.

Scheler, Max. (1915/1963). Liebe und Erkenntnis. Gesammelte Werke Bd. VI. Toim. Maria Scheler ja Manfred Frings. Bern - Munchen.

Shibayama, Zenkei (1991). "Zen Comments on the Mumonkan", teoksessa John Koller \& Patricia Koller (toim.) Sourcebook in Asian Philosophy. New York: MacMillan.

Siegel, Harvey (1988). Educating Reason. London: Routledge.

Sihvola, Juha. (1994). "Aristoteles, emootiot ja rakkaus", teoksessa Hyvän elämän politiikka. Näkökulmia Aristoteleen poliittiseen filosofiaan. Tutkijaliitto.

Wood, W. Jay. (1998) Epistemology. Becoming Intellectually Virtuous. Downers Groe, Ill.: Inter Varsity Press.

Yob, Iris M. (1997) "The Cognitive Emotions and Emotional Cognitions". Teoksessa Harvey Siegel (toim.) Reason and Education. Essays in Honour of Israel Scheffler. Dordrecht: Kluwer.

Zagzebski, Linda (1996) Virtues of the Mind. An Inquiry into the Nature of Virtue and the Ethical Foundations of Knowledge. Cambridge University Press.

Artikkeli saapui toimitukseen 18.2.2004. Se hyväksyttiin julkaistavaksi toimituskunnan kokouksessa 15.4.2004. 